\title{
Thematic Symposium: Business Ethics, Peace and Environmental Issues (T0004)
}

\author{
Michael S. Aßländer ${ }^{1}$. Tobias Gössling ${ }^{2}$
}

Received: 24 July 2017 / Accepted: 27 July 2017 / Published online: 23 August 2017

๑) Springer Science+Business Media B.V. 2017

Large parts of the recent business ethics debate either focus on ethical behavior in and of companies or discuss corporate duties vis-à-vis its stakeholders. Also theories on Corporate Social Responsibilities or Corporate Citizenship often take a management perspective putting duties of business organizations in the center of their considerations. Less attention is paid to the influence of business in the broader ecological and social context. Thus, for example, environmental threads such as ozone depletion or global warming are directly linked to our way of doing business. The same is true also in the social context. Here business activities may influence the social stability of regions or countries, like it can be seen actually in Greece and other South European countries. This shows that corporations' impact on the macrolevel deserves more scholarly attention in the field of business ethics.

Therefore, it was the aim of the 28th European Business Ethics Network Annual Conference June 26-28, 2015, in Istanbul to discuss business ethics in its broadest perspective. The conference, titled "Business Ethics, Peace and Environmental Issues," was organized by the Turkish Network for Business Ethics (EBEN-TR) together with the Hacetepe University Center for Business and Professional Ethics. The contributions presented at the conference encompassed a broad array of topics. The following selection of articles for our thematic symposium "Business Ethics, Peace and Environmental Issues" mirrors this broad spectrum of subjects. We will start with an empirical study by Gok et al. (2017) concerning the influence of moral leadership on workers' moral attitude. As the authors show, ethical leadership proves to be less influential in cases where the workforce already possesses a heightened

Michael S. Aßländer

michael.asslaender@tu-dresden.de

1 Internationales Hochschulinstitut Zittau, Technische Universität Dresden, Markt 23, 02763 Zittau, Germany

2 Organization Studies, TSB \& TSC, Tilburg University, Tilburg, The Netherlands level of moral awareness. In the following article, van den Broek et al. (2017) analyze how corporations react to online protests and how such protests may influence consumers' behavior. While, as the authors found, the negative effects on consumers' buying decisions can be remedied more easily, the negative effects on the brand image caused by online protests will last longer. In their theoretical article on the interrelation between sustainability and well-being, PainterMorland et al. (2017) focus on our common understanding of "well-being = wealth" in the sustainability discussion. Based on the works of Georges Bataille, the authors claim for a mind shift and espouse a more comprehensive understanding of "sustainable development." André et al. (2017) then explore the intentions of money lenders financing projects on crowdfunding platforms. Using the works of Marcel Mauss as theoretical frame, they show that crowdfunding platforms foster specific kinds of relationships which are based rather on a sense of reciprocity than on pure altruistic intentions of the lenders. Our short selection concludes with an article of Wagner and Seele (2017) concerning the new GRI reporting standards G4. In their contribution, the authors discuss whether the newly developed standard might serve as an effective means of communication, thus fostering the idea of a deliberative democracy.

As editors and on behalf of the EBEN Executive Committee, we would like to thank all the participants of the 28th European Business Ethics Network Annual Conference who came to Istanbul from round the world and thus made the conference a success. Our special appreciation goes to the invaluable work of all our colleagues who agreed to serve as anonymous reviewers and thus helped to edit this thematic symposium.

\section{Compliance with Ethical Standards}

Conflict of interest All the authors declare that they have no conflicts of interest. 
Ethical Approval This article does not contain any studies with human participants or animals performed by any of the authors.

\section{References}

André, K., Bureau, S., Gautier, A., \& Rubel, O. (2017). Beyond the opposition between altruism and self-interest: Reciprocal giving in reward-based crowdfunding. Journal of Business Ethics. https:// doi.org/10.1007/s10551-017-3652-x

Gok, K., Sumanth, J. J., Bommer, W. H., Demirtas, O., Arslan, A., Eberhard, J., et al. (2017). You may not reap what you sow: How employees' moral awareness minimizes ethical leadership's positive impact on workplace deviance. Journal of Business Ethics. https://doi.org/10.1007/s10551-017-3655-7

Painter-Morland, M., Demuijnck, G., \& Ornati, S. (2017). Sustainable development and well-being: A philosophical challenge. Journal of Business Ethics. https://doi.org/10.1007/s10551-017-3658-4

van den Broek, T., Langley, D., \& Hornig, T. (2017). The effect of online protests and firm responses on shareholder and consumer evaluation. Journal of Business Ethics. https://doi.org/10.1007/ s10551-017-3653-9

Wagner, R., \& Seele, O. (2017). Uncommitted deliberation? Discussing regulatory gaps by comparing GRI 3.1 to GRI 4.0 in a political CSR perspective. Journal of Business Ethics. https://doi. org/10.1007/s10551-017-3654-8 